\title{
Evaluation of the Yield Strength of a Carbon Composite Material Prepared by Wet Lamination and Vacuum Bag Molding
}

\author{
Radoslav Vandžura, Vladimír Simkulet, Michal Hatala, \\ Darina Dupláková, František Botko
}

\begin{abstract}
Faculty of manufacturing technologies with the seat in Prešov, Technical university of Košice Bayerova 1, 08101 Prešov
\end{abstract}

\begin{abstract}
To evaluate tensile strength of the carbon composite material we used method of static tensile test according to the STN EN ISO 6892-1:2010-01 standard. The material for the production samples from the composite material was carbon fabrics KORDCARBON $\quad 200 \mathrm{~g} / \mathrm{m}^{2} \quad$ - Twill weave. KORDCARBON $160 \mathrm{~g} / \mathrm{m}^{2}$ - Plain weave reinforced with epoxy resin Letoxid PR220+hardener EM315. The carbon composite for the test was prepared by Hand lay-up technology and Vacuum Bag molding method. Orientation to the layer laying direction of the individual samples in the test composite material influences the mechanical properties of the carbon fiber composite material produced by Hand lay-up technology and VMB- Vacuum molding bag method.
\end{abstract}

Keywords - Carbon fibre, Composite materials, Vacuum Bag Molding, Tensile test.

\section{Introduction}

Composite materials or composites are materials assemblage of two or more materials with different properties (shown in Figure 1).

DOI: $10.18421 /$ TEM103-06

https://doi.org/10.18421/TEM103-06

Corresponding author: Darina Duplakova,

Technical University of Kosice, Faculty of Manufacturing Technologies with a seat in Presov, Bayerova 1, 08001 Presov, Slovakia.

Email: darina.duplakova@tuke.sk

Received: 18 May 2021.

Revised: 01 July 2021.

Accepted: 08 July 2021.

Published: 27 August 2021.

(cc) BY-NC-ND (C) 2021 Radoslav Vandžura et al; published by UIKTEN. This work is licensed under the Creative Commons Attribution-NonCommercial-NoDerivs 4.0 License.

The article is published with Open Access at www.temjournal.com
The resulting material has better properties than the original components [1], [2].

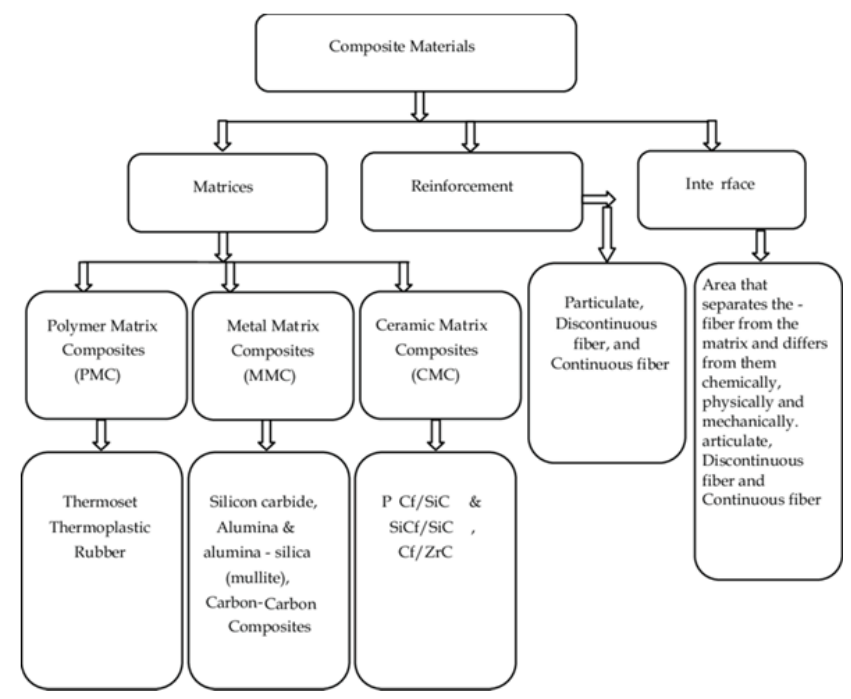

Figure 1. Diagram of composite material structures [3]

Development of composite materials for a specific way of their stress includes concurrent:

- construction (shape) of the component;

- design of the "structure" of the material;

- design of the most suitable production technology.

The composite may only be a heterogeneous material which:

- was created artificially;

- consists of several chemically significantly different components (at least of two, of which at least one is solid) with macroscopically recognizable phase interfaces;

- the individual components are macroscopically uniform distribution in full volume.

Carbon fibers and composites made of carbon fibers are modern new materials with many properties such as high tensile strength, high thermal conductivity, high fracture toughness, and low coefficient of thermal expansion and more [4], [5]. 
Carbon fibers with epoxy or polymer matrix are the most commonly carbon composites, and they can be used to many applications [6], [7]. This is mainly due to the fact that they have one of the best ratios of stiffness and weight.

The fiber-shaped reinforcement can be long, uninterrupted along the entire length of the part, or short. The fibers are always much stronger than the same materials in a compact form. The strength of the fibers increases with decreasing cross-section, because the natural defects of the structure are also small in small diameter fibers and favorably oriented with their further dimension in the fiber axis direction.

To produce carbon composites two most commonly methods are used: wet lamination and vacuum bag molding [8]. These technologies are most used due to their simplicity and availability.

Many authors have been interested in the mechanical properties of reinforced carbon fibers [9], [10], [11]. Most of the tested carbon composites have different mechanical properties which is dependent on used production technology, type of fabric, and resin. Finally, it includes the number of layers and method of depositing the individual layers.

Hand lay-up technology (shown in Figure 2) is method used mainly in the production of car body parts, in the production of various prototypes, in the production of molds by copying models for further lamination and most importantly, it is also used to produce carbon composites. The production of components by this method is undemanding, inexpensive and various sizes of components and molds can be produced. Separation material such as wax, various types of separators and their combinations, is applied to the mold. The main purpose of the separator is that the composite component does not stick to the mold and can be removed from the mold without problems. After applying and drying the separator, a layer of resin is applied to the mold. A layer of fabric is then deposited, which is saturated with resin using a brush or laminating roller. The process of depositing and saturating the layers is repeated until the desired number of layers is reached. After curing, the composite component can be removed from the mold and further modified. Various sources and procedures mention the use of gelcoat as the first layer that is creating a smooth surface for the product [11], [12].

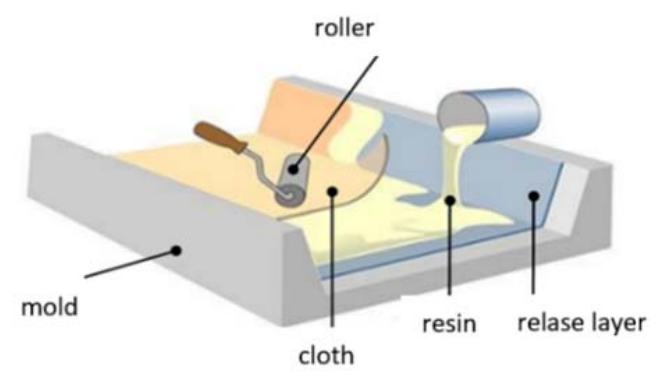

Figure 2. Hand lay-up technology scheme [1]

The method of Vacuum Bag molding (VBM) technology (shown in Figure 3) directly follows the technology of manual wet lamination. The procedure for layering the composite material is the same except that in this technology, a perforated separating film and a layer of absorbent material are placed on the supersaturated layers by resin weaving. The mold with these layers is placed in a vacuum bag and the air is sucked off. The absorbent fabric absorbs excess resin through the perforated film. The vacuum compresses the individual layers of the composite and removes excess air and resin [13], [14].

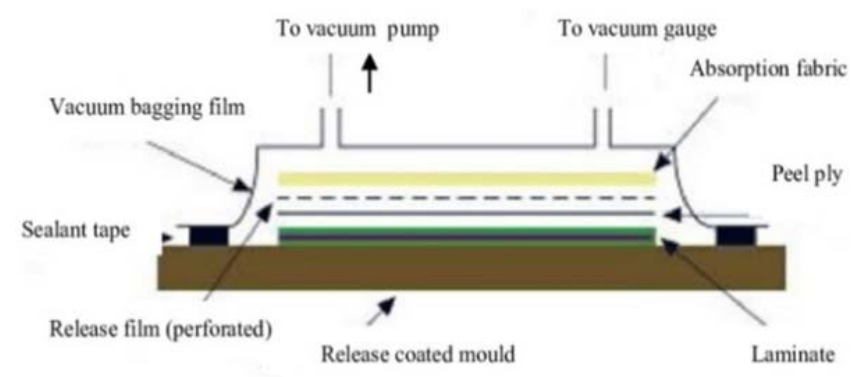

Figure 3. VBM technology scheme [13]

\section{Experimental Procedure}

Samples for the tensile test were CNC milled from a carbon composite board. 3 sets of samples (A, B, C) were created with different angle storage, which is shown in Figure 4.

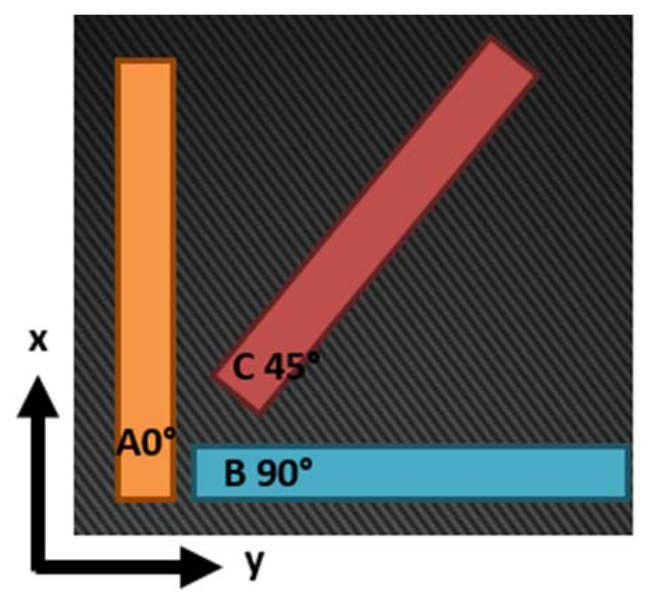

Figure 4. Places of samples in tested composite plate 
Preparation of a plate of carbon fiber composite material is as follows. The process of saturating carbon fabrics with epoxy resin and depositing individual layers is shown in Table 1.

Used epoxy resin Letoxide PR220 + hardener EM315 ratio 100:40 From the 5M company (Figure 5). Certified for aviation use, for cars and motorcycles bodywork construction, for universal use, and it is nonylphenol-free. The mixing ratio is 100: 40 (resin: hardener).

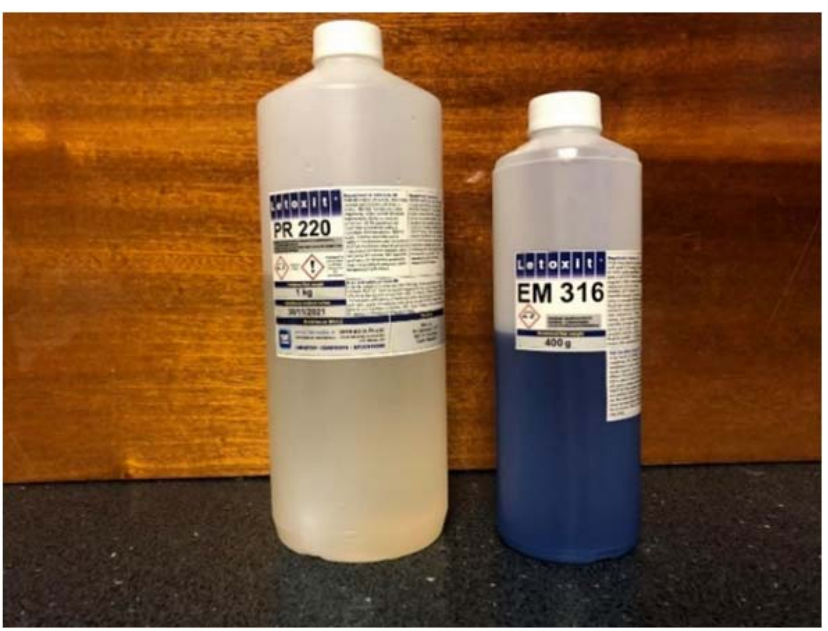

Figure 5. Used material for experiment

This lamination system is certified for applications and lamination with glass, carbon, or kevlar fabrics. Letoxide resin is made based on dian epoxy resin modification. The recommended processing temperature is $20-25^{\circ} \mathrm{C} .0$

Table 1. Composition of the layers of the tested composite material

\begin{tabular}{|c|c|c|c|}
\hline & 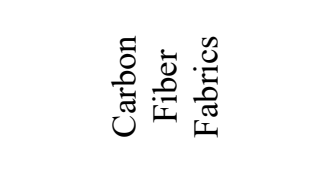 & 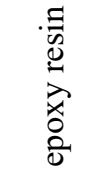 & $\begin{array}{l}\frac{0}{60} \\
\stackrel{\Xi}{\sigma}\end{array}$ \\
\hline 1.Layer & $\begin{array}{c}\text { KORDCARBON } \\
\text { 200g/ } / \mathrm{m}^{2} \text {-twill weave }\end{array}$ & \multirow{6}{*}{ 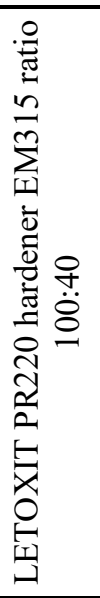 } & $0^{\circ}$ \\
\hline 2.Layer & $\begin{array}{l}\text { KORDCARBON } \\
\text { 160g/m2-plain weave }\end{array}$ & & $0^{\circ}$ \\
\hline 3.Layer & $\begin{array}{c}\text { KORDCARBON } \\
200 \mathrm{~g} / \mathrm{m}^{2} \text {-twill weave }\end{array}$ & & $0^{\circ}$ \\
\hline 4.Layer & $\begin{array}{c}\text { KORDCARBON } \\
160 \mathrm{~g} / \mathrm{m} 2 \text {-plain weave }\end{array}$ & & $0^{\circ}$ \\
\hline 5.Layer & $\begin{array}{c}\text { KORDCARBON } \\
200 \mathrm{~g} / \mathrm{m}^{2} \text {-twill weave }\end{array}$ & & $0^{\circ}$ \\
\hline 6.Layer & $\begin{array}{l}\text { KORDCARBON } \\
\text { 160g/m2-plain weave }\end{array}$ & & $0^{\circ}$ \\
\hline
\end{tabular}

The final board of the material has the dimension: $300 \mathrm{~mm} \times 400 \mathrm{~mm} \times 1,75$ thickness.

Carbon fiber fabrics: The following fabrics were used for testing material production:

- KORDCARBON fabric $200 \mathrm{~g} / \mathrm{m}^{2}$ - Twill weave (Figure 6a)

- KORDCARBON fabric $160 \mathrm{~g} / \mathrm{m}^{2}$ - Plain weave (Figure 6b)

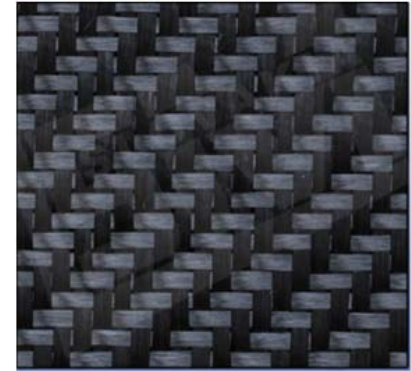

a) Twill

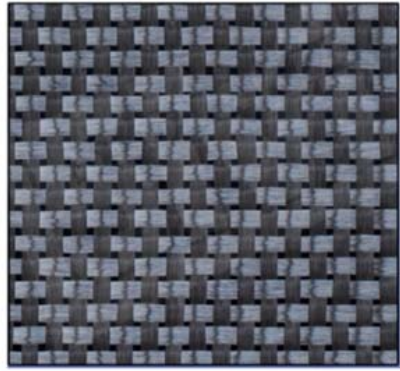

b) Plain
Figure 6. Weave Carbon fiber 0

The samples have the shape and dimension according to the STN EN ISO 6892-1:2010-01 standard (Figure 7). A series of sample A (A1, A2, $\mathrm{A} 3), \mathrm{B}(\mathrm{B} 1, \mathrm{~B} 2, \mathrm{~B} 3), \mathrm{C}(\mathrm{C} 1, \mathrm{C} 2, \mathrm{C} 3)$ were $\mathrm{CNC}$ milled from a prepared carbon composite plate. The static tensile test was performed on a FM-1000 machine according to the STN EN standard (shown in Figure 8).

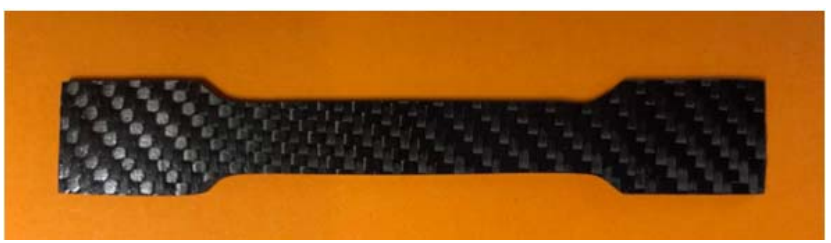

Figure 7. Example of sample for tensile test

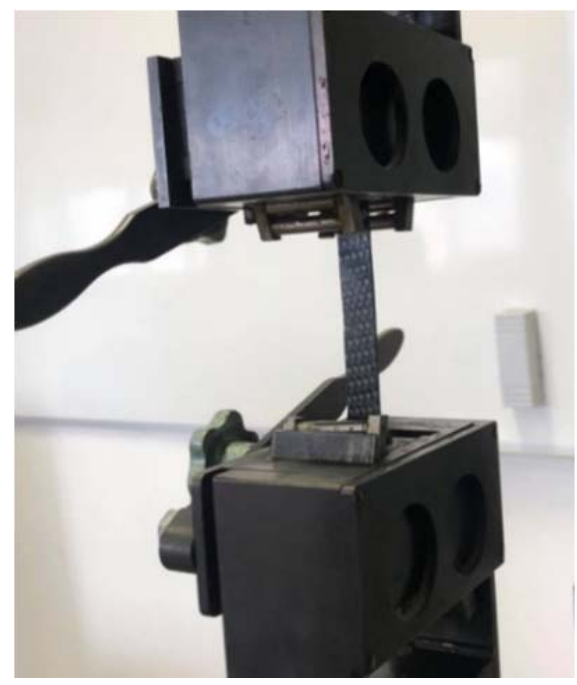

Figure 8. Sample of material during Tensile test 


\section{Results and Discussion}

The individual sample tensile test results for all samples (shown in Figure 14) are presented in Table 2.

\section{Table 2. Tensile test data}

\begin{tabular}{|c|c|c|c|c|c|c|c|c|c|}
\hline & \multicolumn{9}{|c|}{ sample } \\
\hline & A1 & A2 & $\mathrm{A}_{3}$ & B1 & B2 & B3 & $\mathrm{Cl}$ & $\mathrm{C} 2_{2}$ & $\mathrm{C} 3$ \\
\hline $\begin{array}{c}\text { Fmax - } \\
\text { measured } \\
\text { force }(\mathrm{N})\end{array}$ & 7700 & 7800 & 7300 & 6400 & 6300 & 6500 & 3200 & 3000 & 3300 \\
\hline $\begin{array}{c}F_{\max } \\
\text { average } \\
\text { (N) }\end{array}$ & \multicolumn{3}{|c|}{7600} & \multicolumn{3}{|c|}{6400} & \multicolumn{3}{|c|}{3167} \\
\hline $\begin{array}{c}\mathrm{S}_{\mathrm{A}} \text { - stress } \\
\text { area } \\
\left(\mathrm{mm}^{2}\right)\end{array}$ & \multicolumn{9}{|c|}{21.86} \\
\hline $\begin{array}{c}\mathrm{Rm} \\
\text { average } \\
(\mathrm{MPa})\end{array}$ & \multicolumn{3}{|c|}{347.43} & \multicolumn{3}{|c|}{292.57} & \multicolumn{3}{|c|}{144,76} \\
\hline $\begin{array}{c}\text { Lo- } \\
\text { overall } \\
\text { length } \\
(\mathrm{mm})\end{array}$ & \multicolumn{9}{|c|}{155} \\
\hline $\begin{array}{c}\varepsilon \text { - relative } \\
\text { elongation } \\
(\%)\end{array}$ & 1.81 & 1.85 & 1.83 & 2 & 1.9 & 2.1 & 0.84 & 0.82 & 0.88 \\
\hline
\end{tabular}

The highest values of the yield strength were reached by samples A (A1, A2, A3) (Figure 9) on average $\mathrm{R}_{\mathrm{m}}=347.43 \mathrm{MPa}$.

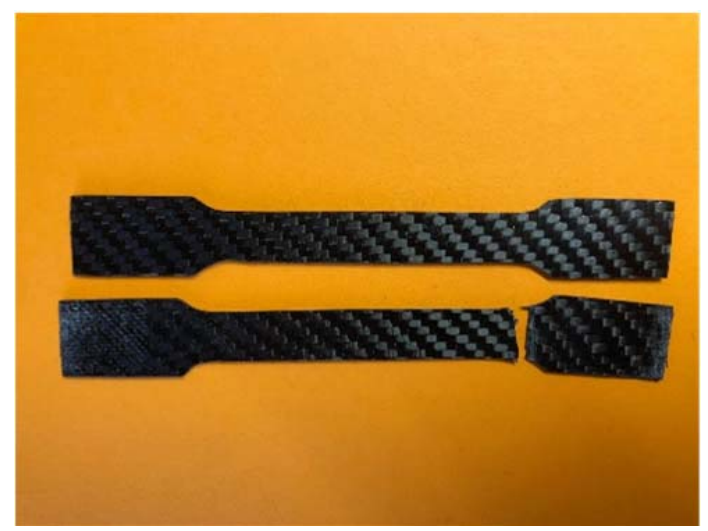

Figure 9. Samples A before (up) and after testing (down)

The lowest values of the yield strength were reached by samples $\mathrm{C}(\mathrm{C} 1, \mathrm{C} 2, \mathrm{C} 3)$ on average $\mathrm{R}_{\mathrm{m}}=$ 144.76 MPa and elongation were reached by samples $\mathrm{C}(\mathrm{C} 1, \mathrm{C} 2, \mathrm{C} 3)$ on average $\varepsilon=0,84 \%$ (shown in Figure 10).

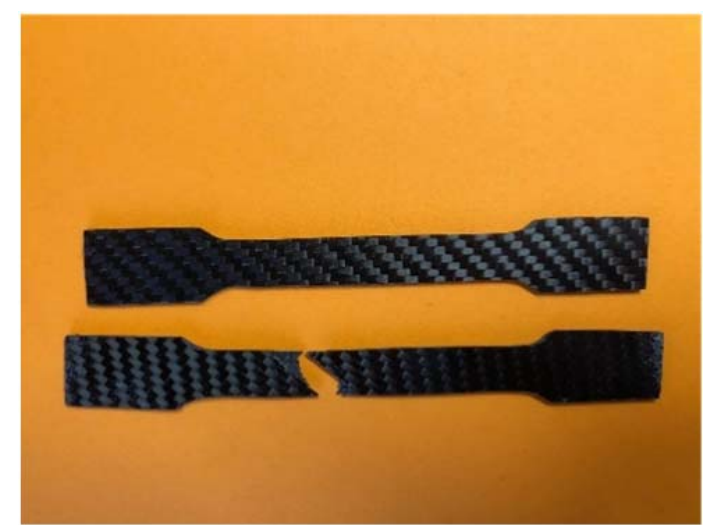

Figure 10. Samples C before (up) and after testing (down)

The highest values of the relative elongation were reached by samples $\mathrm{B}(\mathrm{B} 1, \mathrm{~B} 2, \mathrm{~B} 3)$ on average $\varepsilon=$ $2 \%$.

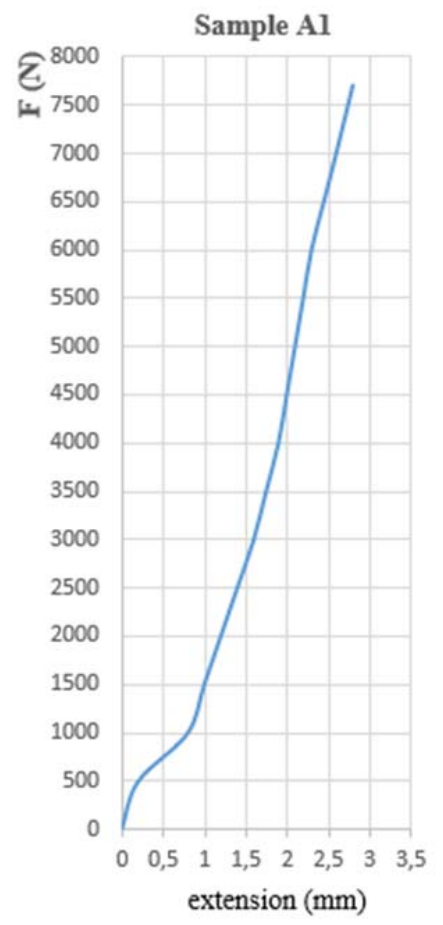

Figure 11. Tensile test (sample A1)

Tensile diagrams for individual selected samples are showed in Figure 11 (A1), Figure 12 (B1), and Figure $13(\mathrm{C} 1)$. From the stress plots for the tensile test samples A1 demonstrate linear behavior until the ultimate failure compared to the other samples. The reason of the non-linearity of the stress-strain curves is due to the epoxy matrix cracking during the tensile test Error! Reference source not found.. 


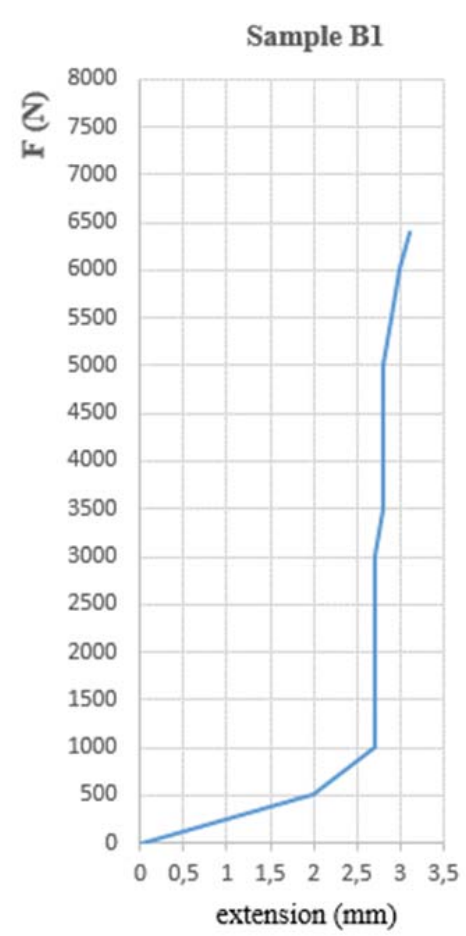

Figure 12. Tensile test (sample B1)

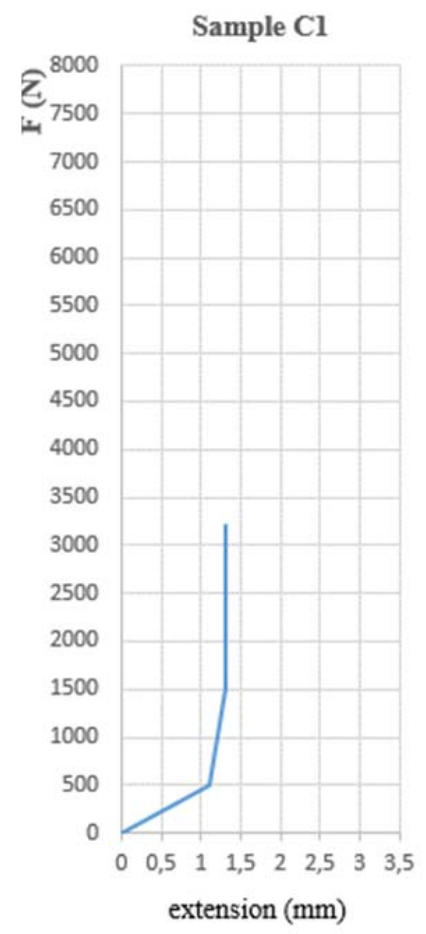

Figure 13. Tensile test (sample C1)

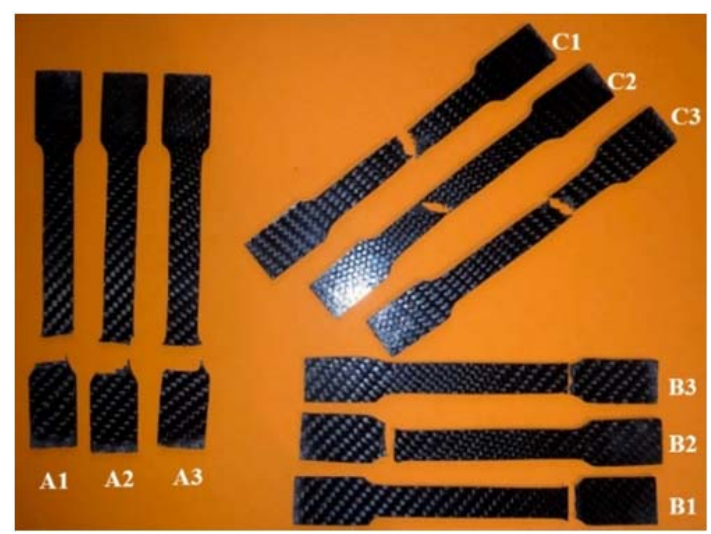

Figure 14. All samples after Tensile test

\section{Conclusion}

From measured tensile test data, we can conclude that the orientation of the individual samples in the test composite material has an effect on the mechanical properties of the carbon fiber composite material produced by Hand lay-up technology and VMB- Vacuum molding bag method.

Samples A (A1, A2, A3) showed the highest $R_{m}$ value $R_{m}$ average: $347,43 \mathrm{MPa}$. The lowest $R_{m}$ values were shown by samples $\mathrm{C}(\mathrm{C} 1, \mathrm{C} 2, \mathrm{C} 3) \mathrm{R}_{\mathrm{m}}$ average: 144,76 MPa. Samples C (C1, C2, C3) were oriented relative to samples $\mathrm{A}(\mathrm{A} 1, \mathrm{~A} 2, \mathrm{~A} 3)$ by $45^{\circ}$.

\section{Acknowledgements}

This research was supported by grants KEGA 018TUKE-4/2021 and VEGA 1/0080/20.

\section{References}

[1]. Murčinková, Z., Živčák, J., \& Zajac, J. (2020). Experimental study of parameters influencing the damping of particulate, fibre-reinforced, hybrid, and sandwich composites. International Journal of Materials Research, 111(8), 688-697.

[2]. Knapčíková, L., Behúnová, A., \& Behún, M. (2020). Using a discrete event simulation as an effective method applied in the production of recycled material. Advances in Production Engineering \& Management, 15(4), 431-440.

[3]. Guggilla, P., \& Batra, A. K. (2011). Novel electroceramic: polymer composites-preparation, properties and applications. IntechOpen.

[4]. Duplák, J., Čuma, M., \& Kormoš, M. (2014). Detail Study and Analysis of Durability for Selected Cutting Materials According to Taylor's Theory. In Key Engineering Materials (Vol. 581, pp. 3-8). Trans Tech Publications Ltd. 
[5]. Teliskova, M., Torek, J., Cmorej, T., Kocisko, M., \& Petrus, J. (2017, April). Adjustments of RepRap type printer workbench. In 2017 4th International Conference on Industrial Engineering and Applications (ICIEA) (pp. 15-19). IEEE.

[6]. Mallick, P. K. (2007). Fiber-reinforced composites: materials, manufacturing, and design. CRC press.

[7]. Chung, D. D. (2010). Composite materials: science and applications. Springer Science \& Business Media.

[8]. Rajak, D. K., Pagar, D. D., Menezes, P. L., \& Linul, E. (2019). Fiber-reinforced polymer composites: Manufacturing, properties, and applications. Polymers, 11(10), 1667.

[9]. AL-Qrimli, H. F., Mahdi, F. A., \& Ismail, F. B. (2015). Carbon/epoxy woven composite experimental and numerical simulation to predict tensile performance. Advances in Materials Science, 4(2), 3341.
[10]. Sun, G., Zuo, W., Chen, D., Luo, Q., Pang, T., \& Li, Q. (2021). On the effects of temperature on tensile behavior of carbon fiber reinforced epoxy laminates. Thin-Walled Structures, 164, 107769.

[11]. Manufacturing and assembly. (2021). Retrieved from:

http://compositesuniversal.com/manufacturing-6.html [accessed: 10 January 2021].

[12]. Kender, Š. (2016). Technológie výroby kompozitov, Retrieved from:

https://www.sjf.tuke.sk/transferinovacii/pages/archiv/t ransfer/33-2016/pdf/188-191.pdf [accessed: 15 March 2021].

[13]. Impacted of Vacuum Bag Woven Kenaf/Fiberglass Hybrid Composite,(2014). Retrieved from:

https://www.researchgate.net/figure/Vacuum-bagmoulding-technique_fig2_270271767 [accessed: 11 May 2021].

[14]. Kordcarbon 200G/M2 Keper - Info shop, Retrieved from: https://eshop.5mslovakia.sk [accessed: 11 May 2021]. 